Thorax, 1980, 35, 807-813

\title{
Atopy and bronchial reactivity in older patients with cystic fibrosis
}

\author{
M J TOBIN, O MAGUIRE, D REEN, E TEMPANY, AND M X FITZGERALD \\ From the Medical Professorial Unit, University College Dublin, St Vincent's Hospital and \\ Children's Research Centre, Our Lady's Hospital for Sick Children, Dublin
}

ABSTRACT We studied 25 adolescent and adult patients with cystic fibrosis (CF) and 25 control subjects to determine if the prevalence of atopy and bronchial hyperreactivity was increased in this disease. Results showed that atopic symptoms, as defined by history, were more frequently present in the CF patients. Prick testing of the skin produced positive reactions in $88 \%$ of the CF group and $36 \%$ of the control subjects $(\mathrm{p}<0.001)$, and the mean number of reactions per subject was significantly higher in the former group $(p<0.001)$; reactions to fungal antigens were strikingly positive in the CF group. The CF patients had a significantly higher mean serum $\operatorname{IgG}_{4}(\mathrm{p}<0.001), \operatorname{IgE}(\mathrm{p}<0.01)$, and higher mean eosinophil count $(p>0.05)$. Clear-cut bronchial hyperreactivity was demonstrated in the CF group compared with control subjects. Bronchial provocation with $400 \mu \mathrm{g}$ of histamine led to a greater than $15 \%$ fall in the preinhalation $\mathrm{FEV}_{1}$ in $35 \%$ of the CF subjects compared with $4 \%$ of the control group, with a mean percentage fall of $15 \%$ and $3 \%$ respectively $(\mathrm{p}<0.001)$. In the CF group a greater than $15 \%$ rise in PEFR occurred in $32 \%$ after inhalation of the parasympatholytic, ipratropium bromide $(54 \mu \mathrm{g})$, and in $27 \%$ after inhalation of the sympathomimetic, fenoterol $(400 \mu \mathrm{g})$. No correlation was found between bronchial reactivity and atopic status, HLA phenotype pattern, or disease severity. The cause of the increased prevalence of atopy and bronchial reactivity in $\mathrm{CF}$ patients remains unknown. However, it is clear that a trial of bronchodilator therapy is warranted in adolescents and young adults with $\mathrm{CF}$.

An increased prevalence of atopy in patients with cystic fibrosis (CF) was first reported by Lowe in $1949 .{ }^{1}$ Since that time, a number of authors studying a variety of atopic indices have published results, some confirming the association, ${ }^{2-6}$ others disputing it. $^{7-9}$ Because of these conflicting results, and because of the difference in methodology used to assess atopy, we undertook a study to define the prevalance of atopy in a group of adolescents and young adults with $\mathrm{CF}$, by examining a comprehensive range of atopic indices. Furthermore, we carried out HLA phenotyping to determine if those CF patients with atopic features constituted a separate. genetically linked subgroup.

The related problem of bronchial reactivity was studied by spirometric measurements before

Presented in part at the Joint Thoracic Society and British Thoracic Association Meeting, February 1980.

Address for reprint requests: Professor MX FitzGerald, Medical Professorial Unit, University College Dublin, St Vincent's Hospital, Elm Park, Dublin 4, Eire. and after inhalation challenge with a bronchoconstrictor, histamine, and two bronchodilators,

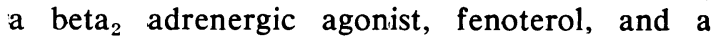
parasympatholytic, ipratropium bromide.

\section{Methods}

Twenty-five documented CF patients, with an age range from 10 to 32 years (mean $17 \mathrm{yr}$ ) were studied. A control group consisted of 25 healthy individuals, with an age range from 10 to 28 years (mean $15.2 \mathrm{yr}$ ). The male-female ratio was identical in each group $(2 \cdot 1: 1)$. The patients were divided into three groups of severity on the basis of clinical and radiological findings. ${ }^{10}$ Consent to carry out the study was obtained from parents of all subjects under 18 years of age.

\section{ALLERGIC PROFILE}

Both patients and control subjects were questioned about a history of wheezing, allergic rhinitis, eczema, "hives", angioneurotic oedema, 
drug allergy, nasal polyposis, and a family history of allergy. Skin hypersensitivity tests were performed with a diluent control, a positive control (histamine acid phosphate), and the following 13 Bencard allergen extracts: house-dust, $D$ pteronyssinus, grass pollen, Timothy grass, tree pollen, feathers, cat fur, Aspergillus fumigatus, Aspergillus terreus, Cladosporium herbarum, and three mixed mould extracts, M5, M10, and M11. The skin tests were performed by the modified prick method on the volar aspect of the forearm, and the weal size in millimetres was recorded 20 minutes after the introduction of the allergen.

Total blood eosinophil counts were determined by the chamber method, using an eosin-acetone diluent. The total serum IgE was determined by the radioimmunoassay technique, and serum $\mathrm{IgG}_{4}$ by a microscale version of a radial immunodiffusion method (antisera obtained from Seward Laboratories, London). ${ }^{11}$ These tests were performed without knowledge of the patients' skin reactivity. Precipitins against Aspergillus fumigatus were determined by the agar-gel diffusion technique, as described by Longbottom and Pepys. ${ }^{12}$

\section{GENETIC STUDIES}

HLA phenotyping was performed by the microlymphocytoxicity technique. The following HLA-A, -B, and -C antigens were determined.

HLA-A: $\quad-1,-2,-3,-9$ (w 23, w 24), $-1-(25,26)$ $-11,-28,-29,-w 23,-w 24,-w 30$, $31,32$.

HLA-B: $\quad-5,-7,-8,-12,-13,-14,-15,-17,-18$, $-27,-40,-w 16,-w 21,-w 22,-w 35$.

HLA-C: $\quad-w 1,-w 2,-w 3,-w 4$.

\section{BRONCHIAL CHALLENGE}

The spirometric measurements made included determination of peak expiratory flow rate (PEFR) using a Wright Peak Flow meter, forced vital capacity (FVC) and forced expiratory volume in one second $\left(\mathrm{FEV}_{1}\right)$ using a dry spirometer (Vitalograph). The best of three attempts was recorded and corrected to BTPS. Not all measurements could be made in all patients during every phase of the study. Routine bronchodilators were previously withheld according to the protocol of Chai et al. ${ }^{13}$ No patient was receiving antihistamine therapy at the time of the study. Both groups were challenged with the bronchoconstrictor, histamine acid phosphate $400 \mu \mathrm{g}$, taken as four individual puffs from a metered inhaler (courtesy of Riker Laboratories). Forced expiratory volume in one second and FVC were per- formed before the challenge and repeated five minutes later; the percentage change was re- के corded. On two separate days, the CF group, but $\mathbb{\otimes}$ not the control subjects inhaled bronchodilators. On the first day, the beta ${ }_{2}$ adrenergic agonist, fenoterol $(400 \mu \mathrm{g})$, was inhaled in two puffs, and. on the second day, the parasympatholytic, ipra- $\vec{\omega}$ tropium bromide $(54 \mu \mathrm{g})$ was inhaled as three puffs from a metered dose inhaler. Forced expira- $\overrightarrow{\vec{x}}$ tory volume in one second, FVC, and PEFR $\dot{\omega}$ were performed at 15,30 , and 60 minutes after administration of each of the two bronchodi- $\overrightarrow{.}$ lators; the maximum rise was recorded, and the percentage change from baseline was calculated.

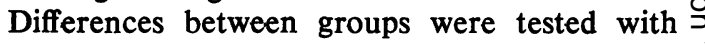
Students' $t$, Mann-Whitney $U$, chi $^{2}$ and Fisher's $\vec{Z}$ exact probability tests, as appropriate. Linear regression analysis was used to look for correlation between values.

\section{Results}

The results of the atopic questionnaire are shown in table 1. All atopic features were reported more commonly in the CF patients, including a marked increase in the reported prevalence of such features in their first degree relatives.

\section{ALLERGIC PROFILE}

The CF group had significantly more positive skin tests than the control subjects, $88 \%$ compared with $36 \%(\mathrm{p}<0.001)$ and the mean number of reactions per individual, 5.5 and 1.5 respectively, was also significantly higher $(\mathrm{p}<0.001)$. Both groups were similar in having the greatest number of positive reactions to house-dust, but the CF group had a far greater number of reactions to the fungal antigens $-A$ fumi-

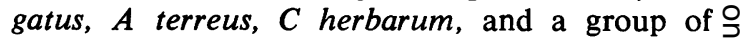
mixed moulds (table 2). The two groups showed $I$

Table 1 Atopic questionnaire in cystic fibrosis patients and control subjects

\begin{tabular}{|c|c|c|c|}
\hline & $\begin{array}{l}\text { Cystic fibrosis } \\
\text { patients } \\
(n=25)\end{array}$ & $\begin{array}{l}\text { Control } \\
\text { subjects } \\
(n=25)\end{array}$ & $p$ value* \\
\hline $\begin{array}{l}\text { Wheeze/asthma } \\
\text { Allergic rhinitis } \\
\text { Hives } \\
\text { Eczema } \\
\text { Nasal polyposis } \\
\text { Angioneurotic oedema } \\
\text { Family history of atopy }\end{array}$ & $\begin{array}{c}44 \% \\
20 \% \\
72 \% \\
8 \% \\
24 \% \\
0 \\
76 \%\end{array}$ & $\begin{array}{l}12 \% \\
0 \\
48 \% \\
4 \% \\
4 \% \\
0 \\
24 \%\end{array}$ & $\begin{array}{l}0.013 \\
0.025 \\
\text { NS } \\
\text { NS } \\
=0.049 \\
\text { NS } \\
<0.001\end{array}$ \\
\hline
\end{tabular}

*Fisher's exact probability test, cystic fibrosis patients versus control subjects.

NS $=$ not significant . 
Table 2 Hypersensitivity skin tests in 25 cystic fibrosis patients and 25 control subjects

\begin{tabular}{|c|c|c|c|c|c|c|}
\hline & \multicolumn{3}{|c|}{$C F$ patients } & \multicolumn{3}{|c|}{ Control subjects } \\
\hline & $\begin{array}{l}\text { Number } \\
\text { positive }\end{array}$ & $\begin{array}{l}\text { Weal } \\
\text { diameter } \\
\geqslant 5 \mathrm{~mm}\end{array}$ & $\begin{array}{l}\text { Mean } \\
\text { weal size } \\
(\mathrm{mm})\end{array}$ & $\begin{array}{l}\text { Number } \\
\text { positive }\end{array}$ & $\begin{array}{l}\text { Weal } \\
\text { diameter } \\
\geqslant 5 \mathrm{~mm}\end{array}$ & $\begin{array}{l}\text { Mean } \\
\text { weal size } \\
(\mathrm{mm})\end{array}$ \\
\hline House dust & 19 & 6 & $4 \cdot 5$ & 7 & 3 & $4 \cdot 7$ \\
\hline A fumigatus & 18 & 12 & $6 \cdot 4$ & 1 & 0 & $2 \cdot 0$ \\
\hline D pteronyssinus & 14 & 5 & $4 \cdot 1$ & 6 & 5 & 6.8 \\
\hline A terreus & 14 & 6 & $4 \cdot 1$ & 2 & 0 & $1 \cdot 5$ \\
\hline Cat fur & 13 & 2 & $3 \cdot 7$ & 5 & 2 & $4 \cdot 0$ \\
\hline Mixed moulds M5 & 12 & 1 & $2 \cdot 9$ & $\mathbf{0}$ & 0 & 0 \\
\hline M10 & 8 & 0 & $2 \cdot 5$ & 1 & 0 & $3 \cdot 0$ \\
\hline M11 & 8 & 0 & $2 \cdot 8$ & 2 & $\mathbf{0}$ & $2 \cdot 0$ \\
\hline Grass pollen & 7 & 4 & 8.6 & 6 & 1 & $2 \cdot 8$ \\
\hline Feathers & 7 & 1 & $2 \cdot 7$ & 5 & 1 & $3 \cdot 4$ \\
\hline Timothy grass & 6 & 4 & $11 \cdot 0$ & 2 & 0 & $2 \cdot 0$ \\
\hline C herbarum & 6 & 0 & 3.0 & 0 & $\mathbf{0}$ & 0 \\
\hline Tree pollen & 5 & 0 & $2 \cdot 8$ & 1 & 0 & $2 \cdot 0$ \\
\hline Control (diluent) & 4 & 0 & $3 \cdot 0$ & 0 & 0 & 0 \\
\hline
\end{tabular}

little difference in the degree of reactivity to pollens and feathers, antigens frequently associated with common atopic disorders. In contrast to the high prevalence of positive reactions to $A$ fumigatus extract, only one patient had precipitins to the fungus in his serum.

Serum immunoglobulin $\mathrm{E}$ was increased above $100 \mathrm{U} / \mathrm{ml}$ in $46 \%$ of the $\mathrm{CF}$ patients, compared with $21 \%$ of the control subjects (figure) and the mean level was significantly higher in the former group $(\mathrm{p}<0.01)$. Total blood eosinophil count was elevated above 400 cells $/ \mathrm{mm}^{3}$ in $33 \%$ of the CF subjects compared with $16 \%$ of the controls, and the mean count in the former was higher $\left(375 / \mathrm{mm}^{3}\right.$ and $268 / \mathrm{mm}^{3}$ respectively), although this difference did not reach statistical significance. Similarly, mean serum $\mathrm{IgG}_{4}$ was significantly higher in the CF patients than the control group ( $\mathrm{p}<0.001$, figure). A significant correlation between the subject's age and the level of $\mathrm{IgG}_{4}$ was found in the CF patients $(r=+0.547$, $\mathrm{p}<0.01$ ) but not the control subjects. No significant correlation was detected between serum $\mathrm{IgG}_{4}$ and $\mathrm{IgE}$ levels.

\section{GENETIC STUDIES}

HLA phenotyping in the total CF group and in those patients with marked atopic features showed no statistically significant difference from the pattern obtained in a group of 253 Irish control subjects (Reen, unpublished data).

\section{BRONCHIAL PROVOCATION}

The results of spirometric testing before and after bronchial challenge with histamine and bronchodilators are shown in tables 3 and 4 . The mean basal $\mathrm{FEV}_{1}$ was significantly lower in the CF group compared with control subjects, 2.06 (60\% of predicted normal value) and $3 \cdot 14(101 \%$ of predicted) litres respectively $(\mathrm{p}<0.01)$. After inhalation of histamine, a greater than $15 \%$ fall in the preinhalation $\mathrm{FEV}_{1}$ was found in $35 \%$ of the CF subjects compared to $4 \%$ of the control subjects $(p<0.05)$, with a mean percentage

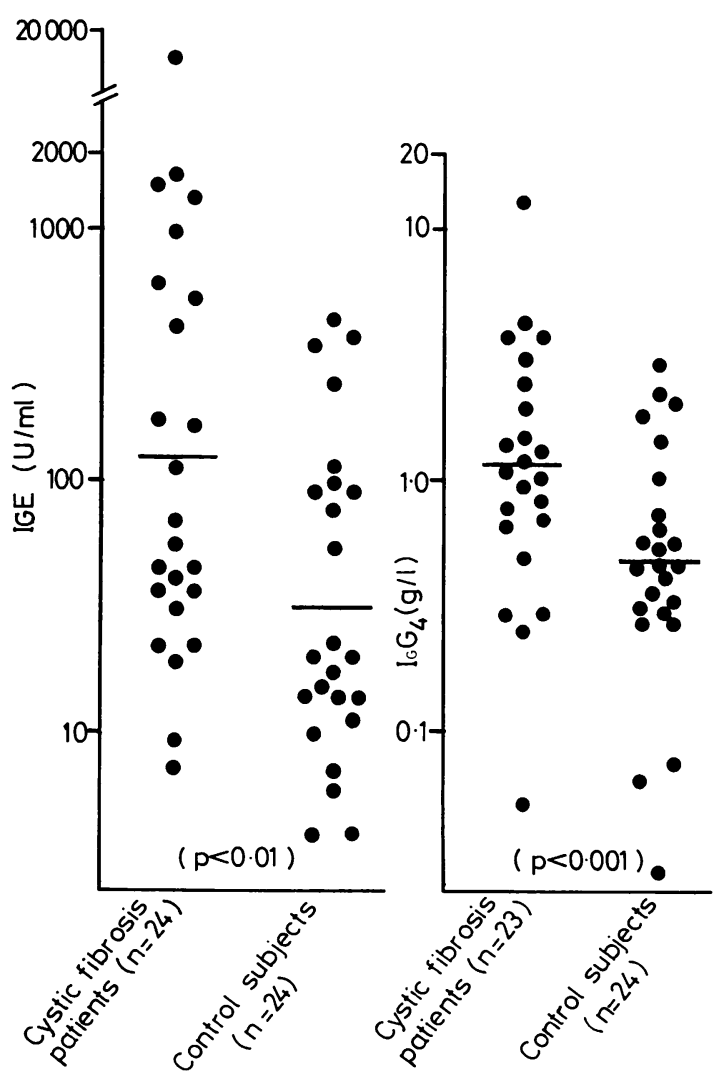

Figure Serum immunoglobulins $E$ and $G 4$ concentrations in patients with cystic fibrosis and control subjects. 
Table 3 Comparison of histamine inhalation $(400 \mu \mathrm{g})$ in cystic fibrosis patients and control subjects

\begin{tabular}{|c|c|c|c|c|c|}
\hline & \multicolumn{2}{|c|}{ Control subjects } & \multicolumn{2}{|l|}{ CF patients } & \multirow[t]{2}{*}{ Value } \\
\hline & Pre & Post & Pre & Post & \\
\hline 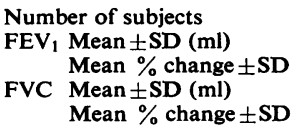 & $\begin{array}{l}25 \\
3144 \pm 911 \\
3444 \pm 1018\end{array}$ & $\begin{array}{l}25 \\
3051 \pm 869 \\
-2 \cdot 8 \pm 4 \cdot 6 \\
3407 \pm 980 \\
-0 \cdot 916 \pm 5 \cdot 1\end{array}$ & $\begin{array}{l}20 \\
2058 \pm 1134 \\
2648 \pm 1085\end{array}$ & $\begin{array}{l}20 \\
1795 \pm 1067 \\
-15 \cdot 2 \pm 13 \\
2380 \pm 1156 \\
-12 \cdot 9 \pm 13 \cdot 5\end{array}$ & $\begin{array}{l}<0.001 \\
<0.001\end{array}$ \\
\hline
\end{tabular}

Table 4 Influence of bronchodilators in cystic fibrosis patients

\begin{tabular}{|c|c|c|c|c|}
\hline & \multicolumn{2}{|c|}{ Ipratropium bromide $(54 \mu \mathrm{g})$} & \multicolumn{2}{|c|}{ Fenoterol $(400 \mu \mathrm{g})$} \\
\hline & Pre & Post & $\overline{\text { Pre }}$ & Post \\
\hline Number of subjects & 22 & 22 & 22 & 22 \\
\hline $\begin{array}{ll}\mathrm{FEV}_{1} & \text { Mean } \pm \mathrm{SD}(\mathrm{ml}) \\
& \text { Mean } \% \text { change } \pm S D\end{array}$ & $1920 \pm 1052$ & $\begin{array}{l}2045 \pm 1105 \\
+7 \cdot 5 \pm 8 \cdot 2\end{array}$ & $1925 \pm 1050$ & $\begin{array}{l}2118 \pm 1058 \\
+9 \cdot 6 \pm 6 \cdot 4\end{array}$ \\
\hline $\begin{array}{ll}\text { FVC } & \text { Mean } \pm S D(m l) \\
& \text { Mean } \% \text { change } \pm S D\end{array}$ & $2501 \pm 967$ & $\begin{array}{l}2675 \pm 938 \\
+8 \cdot 9 \pm 13 \cdot 2\end{array}$ & $2545 \pm 1076$ & $\begin{array}{r}2770 \pm 1048 \\
+11.9 \pm 10.1\end{array}$ \\
\hline $\begin{array}{l}\text { PEFR Mean } \pm \text { SD }(1 / \text { min }) \\
\text { Mean } \% \text { change } \pm S D\end{array}$ & $309 \pm 108$ & $\begin{array}{r}331 \pm 109 \\
+8 \cdot 2 \pm 9 \cdot 2\end{array}$ & $303 \pm 122$ & $\begin{array}{r}331 \pm 116 \\
+12 \cdot 2 \pm 13 \cdot 3\end{array}$ \\
\hline
\end{tabular}

fall of $15 \cdot 2 \%$ and $2 \cdot 8 \%$ and mean absolute falls of 263 and $93 \mathrm{ml}$ respectively $(\mathrm{p}<0.001)$. A trivial rise in $\mathrm{FEV}_{1}$ after inhalation of histamine occurred in one of the CF patients and five of the control subjects. A less striking effect on the FVC was observed, with a greater than $15 \%$ fall in the preinhalation value occurring in $25 \%$ of the CF patients compared with none of the control subjects $(\mathrm{p}<0.05)$; the mean percentage fall was $13 \%$ and $1 \%$ and the mean absolute fall was 268 and $37 \mathrm{ml}$ respectively $(\mathrm{p}<0.001)$. The relationship between severity of the underlying airway obstruction and the response to histamine challenge was examined. Regression analysis of basal $\mathrm{FEV}_{1}$ against percentage change after histamine showed no correlation. Two patients with basal FEV 1 levels which were $98 \%$ and $102 \%$ of the predicted normal values had falls of $22 \%$ and $19 \%$ in $\mathrm{FEV}_{1}$ respectively, indicating that bronchoconstriction was not confined to patients with reduced baseline values.

The results of bronchodilator administration in the CF group are set out in table 4. After ipratropium bromide, a greater than $15 \%$ rise in PEFR, FEV $_{1}$, and FVC occurred in $32 \%, 23 \%$, and $27 \%$ respectively. The patient group as a whole showed a mean percent rise in PEFR, FEV , $_{1}$ and FVC of $8.2 \%, 7.5 \%$, and $8.9 \%$, and a mean absolute rise of $221 / \mathrm{min}, 125 \mathrm{ml}$, and $174 \mathrm{ml}$ respectively. Inhalation of fenoterol induced a greater than $15 \%$ rise in PEFR, FEV $_{1}$, and FVC in $27 \%$, $14 \%$, and $18 \%$ of the patients, with a mean percentage rise of $12.2 \%, 9.6 \%$, and $11.9 \%$, and a mean absolute rise of $281 / \mathrm{min}, 193 \mathrm{ml}$, and $225 \mathrm{ml}$ respectively.
GRADING OF DISEASE SEVERITY

The patients were divided into three groups in increasing order of severity: group 1 consisted of 10 patients, group 2 of six, and group 3 of nine. In these three small subgroups, it was not possible to relate clearly the severity of disease with the number of atopic features present, or the degree of bronchial reactivity.

\section{Discussion}

This comprehensive study of atopic indices in $\mathrm{CF}$, has permitted us to confirm and extend previous observations on this association. Our CF patients, compared with control subjects, demonstrated a striking prevalence of atopic features as judged by prick testing of the skin, total serum IgE levels, total eosinophil counts, serum $\mathrm{IgG}_{4}$ levels, and an atopic questionnaire. The related problem of bronchial reactivity has been similarly defined in more detail, using a variety of bronchoconstrictor and bronchodilator challenges. Comparing our data with results of previous studies, interesting differences and similarities are noted.

Positive skin tests were observed more frequently in the CF group than in the control group, $88 \%$ and $36 \%$ respectively, and the former also had significantly more reactions per individual. In contrast to the previous reports of a relatively low frequency of reactions to housedust and house-dust mite in CF patients, ${ }^{6} 1415$ they produced the greatest number of positive reactions in our patients. The increased sensitivity to house-dust and house-dust mite noted in our 
patients may reflect the fact that they were older than the patients in other studies. This is in accordance with the results of another study of ours $^{16}$ which showed that the frequency of positive skin tests in $\mathrm{CF}$ increases with age. An increased prevalence of sensitivity to fungal antigens, as observed in our study, has been noted by previous authors. ${ }^{3} 101417$ Total IgE levels were significantly higher in the CF group. This supports a similar finding by Wallwork, ${ }^{18}$ but contrasts with Bardana's ${ }^{19}$ report of normal IgE values in a study of $61 \mathrm{CF}$ patients. In the present study, elevated IgE levels were found predominantly in subjects displaying the greatest degree of skin reactivity.

Serum $\operatorname{IgG}_{4}$, the $\operatorname{IgG}$ subclass known to be associated with some atopic reactions, ${ }^{20}{ }^{21}$ again was significantly higher in the CF group. This confirms a similar finding by Shakib. ${ }^{22}$ We found no significant correlation between individual IgE and $\mathrm{IgG}_{4}$ levels, which suggests that each immunoglobulin reflects a different pathway in the pathogenesis of atopy in CF.

The reason for the increased prevalence of atopy in CF is unknown. One possibility is that the phenomenon is acquired as a result of increased antigen access to the IgE producing cells in the submucosa. Mechanisms which might be responsible include abnormal mucosal permeability, a defective secretory IgA system, ${ }^{23}$ trapping of antigen in infected areas of the lung, or failure of antigen clearance because of a ciliotoxic factor. An alternative explanation is that there is a genetic linkage between the CF gene and genes controlling atopic response. In our study, there was a significantly increased family history of atopy in the CF group. However, one must have reservations about comparisons between historical data derived from frequently interviewed patients, and those obtained from healthy control subjects. Although Warner ${ }^{24}$ found an increased personal history of atopy and positive skin tests in a study of obligate heterozygotes, a separate study of ours ${ }^{16}$ suggests that there is no significant difference between positive skin tests in obligate heterozygotes and control subjects. In view of Soothill's ${ }^{25}$ finding of an increased prevalence of HLA-A1 and B8 among infants with positive skin tests, we examined the HLA phenotype pattern of our patients, but failed to detect linkage of atopy to any particular HLA antigen.

The frequent association of bronchial hyperreactivity with atopy has led a number of investigators to study the response to inhaled bronchoconstrictors and bronchodilators in CF.
Haluszka ${ }^{26}$ and Mellis $^{27}$ performed bronchial provocation in $\mathrm{CF}$, using varying doses of histamine, and found a positive response in $68 \%$ and $24 \%$ respectively. In contrast, we used a fixed dose of histamine $(400 \mu \mathrm{g})$ and demonstrated a greater than $15 \%$ fall in $\mathrm{FEV}_{1}$ in $35 \%$ of the CF group, compared with $4 \%$ of the control group, with a mean percentage fall of $15 \%$ and $3 \%$ respectively. We found no significant correlation between bronchial reactivity to histamine and the degree of airway obstruction in our CF patients. Indeed, two patients with basal $\mathrm{FEV}_{1}$ levels which were $98 \%$ and $102 \%$ of the predicted normal values showed marked drops of $22 \%$ and $19 \%$ respectively. This contrasts with the assertion of Mellis $^{27}$ that significant bronchoconstriction only occurred in those patients whose basal pulmonary function was abnormal.

This bronchoconstrictor response may result either from a direct local effect on airway smooth muscle or from vagally mediated reflex bronchoconstriction. ${ }^{28}$ Empey ${ }^{29}$ demonstrated marked histamine reactivity after an upper respiratory tract infection, presumably the result of epithelial damage and exposure of nerve endings. Possibly, in $\mathrm{CF}$ there may be increased sensitivity of the bronchial mucosal receptors caused by chronic infection. Furthermore, the ability to form histamine is increased in chronic inflammatory conditions, because of adaptation in the production of histidine decarboxylase, and this might also contribute to the bronchial hyperirritability in this disease. ${ }^{30}$

There have been conflicting reports on the response to bronchodilators in CF. After inhalation of nebulised adrenaline or isoprenaline, some found a reduction in airway obstruction, ${ }^{31-34}$ others noted no change. ${ }^{35-38}$ The parasympathetic antagonist atropine sulphate was used in one study and found to be superior to isoprenaline. ${ }^{34}$ As isoprenaline and atropine are now unsuitable for clinical use, we examined the response to a selective beta $_{2}$ adrenergic agonist, fenoterol, and a parasympatholytic, ipratropium bromide. Both were administered by metered dose inhalers, in which they are routinely prescribed, and so the results have more direct implications than if the drugs were administered from a special nebuliser or by a positive pressure device. Although the mean rise in PEFR after each agent was undramatic, almost half the patients experienced a greater than $15 \%$ rise in PEFR after inhalation of ipratropium bromide or fenoterol or both. Such an increment is often clinically worthwhile, particularly in those patients with reduced baseline values. The fact that more patients responded to 
the parasympatholytic, ipratropium bromide, than to fenoterol is in accordance with Mitchell's observations, ${ }^{39}$ that $51 \%$ of unselected CF patients had a positive response to methacoline. The more selective responsiveness to a parasympatholytic agent in our patients is similar to the pattern observed in chronic bronchitis by some workers. ${ }^{40} 41$

The cause of the bronchial hyperreactivity in cystic fibrosis is unknown. Although there is a disputed association between bronchial hyperreactivity and atopic status in asthmatics, ${ }^{42-43}$ we found no association between atopy and bronchial responsiveness to histamine, fenoterol, or ipratropium bromide in our cystic fibrosis subjects. This contention is supported by two other studies in $\mathrm{CF}$, which have shown no correlation between exercise-induced bronchial lability ${ }^{4}$ or histamineinduced bronchonstriction ${ }^{27}$ and atopic status.

Authors have contended that atopy ameliorates, ${ }^{944}$ worsens, ${ }^{517}$ or has no effect $^{845}$ on the natural history of CF. In the present study, a wide spectrum of disease severity was observed, and no clear relationship with either atopic status or bronchial reactivity was observed. It is difficult, however, to draw conclusions from the small number of patients studied.

Our results show that there is a higher prevalence of atopy in CF as determined by a comprehensive group of atopic indices. The cause of atopy in this disease remains unknown. It may be caused by increased antigen access or there may be genetic linkage between atopy and CF. No relationship was found between atopic status and severity of the underlying condition, suggestthat atopic status is not of prognostic value in CF. Likewise, the degree of atopy did not correlate with the degree of bronchial reactivity. As a significant proportion of the patients show reversibility in airway obstruction, a trial of bronchodilator therapy, with a beta ${ }_{2}$ adrenergic agonist or a parasympatholytic or both, should be considered in adolescent and young adults with cystic fibrosis.

We are grateful to the Medical Research Council of Ireland who supported this study. We are indebted to the control subjects and the patients who took part in this study and without whose co-operation it would not have succeeded. We thank Mr L Daly, Department of Community Medicine and Epidemiology, University College, Dublin for providing statistical guidance, and Mr M Cogan, Mrs G Lawless, and Mrs N Martin for technical assistance.
References

1 Lowe CU, May CD, Reed SC. Fibrosis of the $\frac{D}{\widehat{D}}$ pancreas in infants and children. Am J Dis Child $\mathrm{Q}$ 1949; 78:349-74.

2 McCarthy DS, Pepys J, Batten J. Hypersensitivity $\vec{\circ}$ to fungi in cystic fibrosis. In: Lawson D. ed. Proceedings of the Fifth International Cystic $\vec{\omega}$ Fibrosis Conference. London: Cystic Fibrosis Research Trust, 1969: 194-204.

3 Warren CPW, Tai E, Batten JC, Hutchcroft BJ, Pepys J. Cystic fibrosis-immunological reactions of to $A$ fumigatus and common allergens. Clin Allergy 1975; 5:1-12.

4 Counahan R, Mearns MB. Prevalence of atopy and exercise-induced bronchial lability in relatives 0 of patients with cystic fibrosis. Arch Dis Child 1975; 50:477-81.

5 Warner JO, Taylor BW, Norman AP, Soothill JF. Association of cystic fibrosis with allergy. Arch Dis Child 1976; 51:507-11.

6 Barron R, Cotton E, Larson G, Brooks J. The prevalence of atopy in cystic fibrosis. CF Club $\vec{\bullet}$ Eighteenth Meeting. San Francisco: CF Foundation, 1977; 23.

7 Abbott V, McCreary JF, Pocock R, Brown A. Fibrocystic disease of the pancreas. Can Med Ass J 1951; 64:419-23.

8 Kulczycki LL, Mueller H, Shwachman H. Respiratory allergy in patients with cystic $\stackrel{\circ}{\mathcal{Q}}$ fibrosis. JAMA 1961; 175:358-64.

9 Rachelefsky GS, Osher A, Dooley RE, Ank B, $\overrightarrow{\vec{o}}$ Stiehm R. Coexistent respiratory allergy and 3 cystic fibrosis. Am J Dis Child 1974; 128:355-9.

10 Mearns M, Longbottom J, Batten J. Precipitating antibodies to Aspergillus fumigatus in cystic fibrosis. Lancet 1967; 1:538-9.

11 Shakib F, Stanworth DR, Drew R, Catty D. A quantitative study of the distribution of $\mathrm{IgG}_{-}^{\times}$ sub-classes in a group of normal human sera. J Immun Meth 1975; 8:17-28.

12 Longbottom JL, Pepys J. Pulmonary aspergillosis: diagnostic and immunological significance of antigens and C-substance in Aspergillus 을 fumigatus. J Pathol Bacteriol 1964; 88:141-51.

13 Chai H, Farr RS, Froehlich LA et al. Standardisation of bronchial inhalation challenge procedures. J Allergy Clin Immunol 1975; 56: ᄋ 323-7.

14 McFarlane H, Allan JD, Van der Zeil P. 옹 Passive cutaneous anaphylaxis (PCA) and $\omega$ specific IgE in cystic fibrosis and their heterozygotes. Clin Allergy 1977; 7:279-84.

15 Warner JO. The variability of skin test hypersensitivity reactions in cystic fibrosis and asthma. $\stackrel{?}{+}$ Clin Allergy 1977; 7:385-9.

16 Reen DJ, Carson J, Maguire O, FitzGerald MX, o Tempany E. Allergy and cystic fibrosis-a study $\mathbb{\mathbb { D }}^{+}$

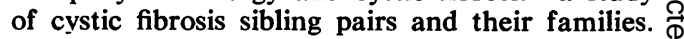

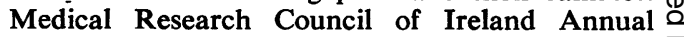
Report 1979/80.

17 Allan JD, Moss AD, Wallwork JC, McFarlane 
H. Immediate hypersensitivity in patients with cystic fibrosis. Clin Allergy 1975; 5:255-61.

18 Wallwork JC, Brenchley $\mathrm{P}$, McCarthy J et al. Some aspects of immunity in patients with cystic fibrosis. Clin Exp Immunol 1974; 18:303-20.

19 Bardana EJ, Sobti KL, Cianciulli Fd, Noonan MJ. Aspergillus antibody in patients with cystic fibrosis. Am J Dis Child 1975; 129:1164-7.

20 Parish WE. Short-term anaphylactic IgG antibodies in human sera. Lancet 1970; 2:591-2.

21 Bryant DH, Burns MW, Lazarus L. New type of allergic asthma due to IgG "reaginic" antibody. Br Med J 1973; 4:589-92.

22 Shakib F, Stanworth DR, Smalley CA, Brown GA. Elevated serum $\mathrm{IgG}_{4}$ levels in cystic fibrosis patients. Clin Allergy 1976; 6:237-40.

23 Wallwork JC, McFarlane $H$. The SIgA system and hypersensitivity in patients with cystic fibrosis. Clin Allergy 1976; 6:349-58.

24 Warner JO, Norman AP, Soothill JF. Cystic fibrosis heterozygosity in the pathogenesis of allergy. Lancet 1976; 1:990-1.

25 Soothill JF, Stokes CR, Turner MW, Norman AP, Taylor B. Predisposing factors and the development of reaginic allergy in infancy. Clin Allergy 1976; 6:305-19.

26 Haluszka J, Scislicki A. Bronchial lability in children suffering from some diseases of the bronchi. Respiration 1975; 32:217-26.

27 Mellis CM, Levison $H$. Bronchial reactivity in cystic fibrosis. Pediatrics 1978; 61:446-50.

28 Gold WM. The role of the parasympathetic nervous system in airways disease. Postgrad Med J 1975; 51 (suppl 7): 53-62.

29 Empey DW, Laitinen LA, Jacobs L, Gold WM, Nadel JA. Mechanisms of bronchial hyperreactivity in normal subjects after upper respiratory tract infection. Am Rev Respir Dis 1976; 113:131-9.

30 Schayer RW. Significance of induced synthesis of histamine in physiology and pathology. Chemotherapia 1961; 3:128-36.

31 Gandevia B, Anderson C. The effect of a bronchodilator aerosol on ventilatory capacity in fibrocystic disease of the pancreas. Arch Dis Child 1959; 34:511-5.

32 Chang $\mathrm{N}$, Levison $\mathrm{H}$. The effect of a nebulized bronchodilator administered with or without intermittent positive pressure breathing on ventilatory function in children with cystic fibrosis and asthma. Am Rev Respir Dis 1972; 106:867-72.

33 Landau LI, Phelan PD. The variable effect of a bronchodilating agent on pulmonary function in cystic fibrosis. $J$ Pediatr 1973; 82:863-8.

34 Larsen GL, Barron RJ, Cotton EK, Brooks JG. A compartive study of atropine sulphate and isoproterenol hydrochloride in cystic fibrosis. Am Rev Respir Dis 1978; 117:298 (Abstr).

35 West JR, Levin SM, di Sant' Agnese PA. Pulmonary function in cystic fibrosis of the pancreas. Pediatrics 1954; 13:155-64.

36 Cook CD, Helliesen PJ, Kulczycki L et al. Studies of respiratory physiology in children. II. Lung volumes and mechanics of respiration in 64 patients with cystic fibrosis of the pancreas. Pediatric 1959; 24:181-93.

37 Mellins RB, Levine OR, Ingram RH, Fishman AP. Obstructive disease of the airways in cystic fibrosis. Pediatrics 1968; 41:560-73.

38 Zapletal A, Motoyoma EK, Gibson LE, Bouhuys A. Pulmonary mechanics in asthma and cystic fibrosis. Pediatrics 1971; 48:64-72.

39 Mitchell I, Corey M, Woenne R, Krastins IRB, Levison $\mathrm{H}$. Bronchial hyperreactivity in cystic fibrosis and asthma. $J$ Pediatr 1978; 93:744-8.

40 Poppius H, Salorinne Y. Comparative trial of a new anticholinergic bronchodilator, Sch 1000 , and salbutamol in chronic bronchitis. $\mathrm{Br}$ Med J 1973; 4:134-6.

41 Chapman T. The effect of Sch 1000 MDI and salbutamol MDI on ventilatory function in patients with chronic bronchitis, assessed by spirometry. Postgrad Med J 1975; 51 (Suppl 7): 112-3.

42 Cockcroft DW, Killian DN, Mellon JJA, Hargreave FE. Bronchial reactivity to inhaled histamine: a method and clinical survey. Clin Allergy 1977; 7:235-43.

43 Bryant DH, Burns MW. The relationship between bronchial histamine reactivity and atopic status. Clin Allergy 1976; 6:373-81.

44 Van Metre TE, Cooke RE, Gibson LE, Winkenwerder WL. Evidence of allergy in patients with cystic fibrosis of the pancreas. J Allergy 1960; 31:141-50.

45 Nelson LA, Callerame MLC, Van Ess JD, Condemi JJ, Schwartz RH. Atopy in cystic fibrosis. CF Club Abstracts, Eighteenth Annual Meeting. San Francisco: CF Foundation, 1977: 70. 